\title{
Health Consequences of Acid Rain in South West Sweden
}

\section{-Influence of Acid Well Water on Health and Hair Mineral Pattern}

\section{Rosborg1, B. Nihlgård²}

${ }^{1}$ Sustainable Development, Environmental Science and Engineering (SEED), School of Architecture and the Built Environment (ABE), KTH Royal Institute of Technology, Stockholm, Sweden ${ }^{2}$ Institute of Biology, Ecology Building, Lund University, Lund, Sweden

Email: irosborg@kth.se, bengt.nihlgard@biol.lu.se

How to cite this paper: Rosborg1, I. and Nihlgård, B. (2018) Health Consequences of Acid Rain in South West Sweden. Journal of Geoscience and Environment Protection, 6, 126-142.

https://doi.org/10.4236/gep.2018.62009

Received: January 9, 2018

Accepted: February 25, 2018

Published: February 28, 2018

Copyright (c) 2018 by authors and Scientific Research Publishing Inc. This work is licensed under the Creative Commons Attribution International License (CC BY 4.0).

http://creativecommons.org/licenses/by/4.0/

\begin{abstract}
Acid rain leads to loss of essential elements from soils and bedrock, causing an imbalance in especially dug well waters, as essential element concentrations decrease and potentially toxic element concentrations increase. In this study 72 private dug wells from acid regions $(\mathrm{pH}<6)$ were compared with 68 wells from an alkaline area on limestone bedrock $(\mathrm{pH}>7.0)$ in South-western Sweden. Women, drinking the water for at least 5 years, were interviewed about their health and water and hair samples were collected. The concentrations of about 40 elements in water and hair were analysed, mostly by ICP-MS. The concentrations of essential elements such as $\mathrm{Ca}, \mathrm{Cr}, \mathrm{Mo}, \mathrm{Se}, \mathrm{K}$, and $\mathrm{SO}_{4}$ as well as the body's buffering agent $\mathrm{HCO}_{3}$ were significantly lower in acid than in alkaline water. The median $\mathrm{Ca}$ concentration was 6 times lower in acid waters, and also in hair compared to alkaline. Median $\mathrm{HCO}_{3}$ was 14 times lower in acid waters. $\mathrm{Mg}$ was similar in both populations, since the Swedish bedrock in general has low $\mathrm{Mg}$ content, even so limestone in the alkaline area. The concentrations of especially $\mathrm{Ca}, \mathrm{Cr}, \mathrm{HCO}_{3}$ and $\mathrm{SO}_{4}$, peaked at $\mathrm{pH} 7.0-8.0$, due to precipitation of carbonates and sulphates in alkaline soils and leaching from acid soils. The levels of toxic metals such as $\mathrm{Cd}$ and $\mathrm{Pb}$ were significantly higher in acid well water. High $\mathrm{Cu}$ concentration from pipes, causing especially diarrhoea, is a serious acidification problem. The contribution of essential elements to the daily intake from these well waters, 2 Litres consumption per day, was from $0 \%$ to above $30 \%$ for some elements, clearly showing that $10 \%$, which is generally predicted, can be exceeded for people with private well waters, as well as provide $0 \%$, which is the case for many acid well waters.
\end{abstract}


Water elements were mirrored in hair, e.g. $\mathrm{Ca}$ and Mo. The loss of essential minerals, and increased concentration of toxic elements in acid well water, caused mineral imbalances in the body, as mirrored in hair. Women living in the acid area reported more negative health changes than women in the alkaline district, during the time they had been drinking their well water. The number of reported heart, intestinal, muscle, and skin problems were between 2 and 9 times higher among women drinking acid than alkaline well water.

\section{Keywords}

Acid Well Water, Hair Nutrients, Minerals, Calcium, Magnesium, Bicarbonate, Health

\section{Introduction}

Combustion of coal and oil causes emissions of $\mathrm{SO}_{2}$, due to the sulphur content of coal and oil from especially proteins. Sulphur reacts with $\mathrm{O}_{2}$ in air, forming $\mathrm{SO}_{2}$ gas. South-western Sweden suffered from acid rain during the 1960'-1990's, as the dominating south-west winds brought $\mathrm{SO}_{2}$ in air and $\mathrm{H}_{2} \mathrm{SO}_{4}$ in rain from continental Europe and the British Isles. The $\mathrm{pH}$ of rain was generally $4-4.5$, and below 4 at occasions [1]. The area sometimes labelled "Acidification banana" (Figure 1), suffered the most, since the rainfall is heaviest in this region, and the bedrock is dominated by hard weathered primary rock bedrock, orto-gneiss and granite, and consequently very sensitive to acidification [2]. Concentrations of mineral elements like $\mathrm{K}$, $\mathrm{Ca}$, Se and $\mathrm{Cr}$ decreased remarkably in soil and stream water, as the nutrients were washed out of soils, and concentrations of toxic elements like $\mathrm{Cd}, \mathrm{Hg}$ and $\mathrm{Pb}$ increased [3]. Fish and shellfish died and problems with rejuvenation were frequently reported [4].

Forests were damaged due to both dry and wet deposition of acidic compounds, and roots of trees were negatively influenced e.g. by aluminium compound precipitates that prevented nutrients to enter roots [5].

Figure 2 is a photo from the acidified area labelled "Acidification banana". This area is highly sensitive to acid rain, since it is dominated by hard weathered gneiss and granite. Spruces and pine trees are dominating species.

Contrary, the Kristianstad flatland is dominated by sandstone on primary rock bedrock, with limestone and alkaline soils on top of the sandstone. Thus, this area is not particularly affected by acid rain.

In a lake in a barren district between the two big lakes, Vänern and Vättern, hundreds of crayfish were still captured in 1965, but only 12 individuals in 1970 and the shells had become soft as silk paper. Only big, old pike and perch were captured. In 1975 blueberry jam diluted with dug well water suddenly was purple instead of dark blue, which it was only the year before, now indicating acidic 




Figure 1. Geological map of Sweden (SGU, Geological Survey of Sweden 2017). Studied acid and alkaline areas.



Figure 2. A picture mirroring the specific nature in the areas of Sweden that suffered the most from acid rain, dominated by spruce and pine trees, granite and gneiss [6].

well water. $\mathrm{pH}$ meter showed $\mathrm{pH}$ 5.8. Two years later a child got severe diarrhoea after drinking infant's formula prepared on dug well water. Copper pipes recently installed were, opposed to older pipes, bendable, as they were produced from a soft alloy, which dissolved copper into the acid water. Water analysis showed elevated copper concentration. Researchers had been discussing copper from pipes due to acid well water and diarrhoea in infants for some time [7]. In- 
stallation of alkaline filter with dolomitic limestone reduced the acidity of water. Thus, the water was also mineralized to some extent as the Ca concentration increased from below $10 \mathrm{mg} / \mathrm{L}$ to slightly above, and the alkalinity, $\mathrm{HCO}_{3}$, increased from about $20 \mathrm{mg} / \mathrm{L}$ to $60 \mathrm{mg} / \mathrm{L}$. Such a filter was regenerated with dolomitic limestone each three months. In one case, the whole family was more alert after each re-generation of the filter, although the mineral levels were still low. This gave an awareness of the importance of minerals from drinking water for proper health.

In 1996 the opportunity to study Acid Rain and health effects appeared. Thus, though long time since the negative health effects were first noticed, a scientific study was initiated.

\section{Material and Methods}

\subsection{Water and Hair Sampling}

In the autumn 199747 women in an acid area and 43 in an alkaline district were randomly selected for water and hair sampling. Since there did not exist any public register on $\mathrm{pH}$ of well waters, driving around in the acid district and alkaline area was the only way to find study subjects. Thus, during the autumn 1997 women were selected through knocking doors in the respective districts. Less than $5 \%$ of women answering the door denied participation in the study. All were living in private houses with private wells (dug wells, no water filter, $\mathrm{pH}<6$ (acid area) and $\mathrm{pH}>7$ (alkaline district), respectively, as tested by a field $\mathrm{pH}$ meter, Knick model 912) all in the "Acidification banana", $\mathrm{pH}<6$, dominated by primary rock bedrock (gneiss and granite), and on the Kristianstad flatland, $\mathrm{pH}>7$, dominated by limestone bedrock and alkaline soils [8]. Women were selected if they had been drinking their specific water for at least 5 years. Three years later another 50 women, 25 from the acid area and 25 from the alkaline, were visited for water and hair sampling in the same regions. Hair samples were obtained from all participants, approximately $3 \mathrm{~cm}(\sim 0.5 \mathrm{~g})$ of hair strands from the proximal end in the occipital region. The same stainless steel scissors were used throughout the study. Hair samples were kept in a closed envelope until the time of analysis. A sample of $250 \mathrm{~mL}$ of water was collected from the kitchen tap of the homes of all participants after half a minute of flushing to avoid corrosion products in the samples, and filled to the top. The water samples were deep frozen within 7 hours and kept in a freezer $\left(-20^{\circ} \mathrm{C}\right)$ until analysis at the Department of Ecology, Lund University, Sweden. The night before the analysis, the water samples were thawed in a refrigerator $\left(+4^{\circ} \mathrm{C}\right)$. No filtering of the water took place before analysis.

\subsection{Health Questionnaires}

A structured health questionnaire was completed during the visit. Women were asked about health changes related to their gastro-intestinal tract, cardiovascular 
system, muscles, renal system, and skin the last five years or more, where number of years were linked to when they started to drink their specific well water. In case health problems had occurred during that time, women were asked in more detail about symptoms. There was also a question regarding food habits.

\subsection{Vegetables and Soil}

To find out whether the differences in hair minerals in the two areas were not only due to different mineral levels in well waters, vegetables were cultivated during the summer 2006 from 60 women participating in the study in 1997. The vegetables were; carrot (Daucus carota L.), parsley (Petroselinum crispum), chive (Allium schoenoprasum) and lettuce (Eruca sativa). The vegetables were harvested in August, and rinsed in tap water from the kitchen of the participating women. Soil samples were taken from the kitchen gardens of the upper 10 $\mathrm{cm}$.

\subsection{Water Analyses}

After thawing and adjusting to room temperature, $\mathrm{pH}$ (Radiometer PHM84, glass electrode) and conductivity (Radiometer CMD92, $20^{\circ} \mathrm{C}$ ) was measured in water samples, with an accuracy of 0.01 for both parameters. The samples were acidified by adding nitric acid $\left(\mathrm{HNO}_{3}\right)$ to $1 \%$ in the original sample bottles before the analysis of metals. $\mathrm{Al}(396.152 \mathrm{~nm}), \mathrm{Ca}(317.933 \mathrm{~nm}), \mathrm{Cu}(324.754 \mathrm{~nm})$, Fe $(238.204 \mathrm{~nm}), \mathrm{K}(766.491 \mathrm{~nm}), \mathrm{Mg}(279.079 \mathrm{~nm}), \mathrm{Mn}(257.610 \mathrm{~nm}), \mathrm{Na}$ $(589.592 \mathrm{~nm})$, and $\mathrm{Zn}(213.856 \mathrm{~nm})$ in the water samples were analyzed by ICP OES (Inductively coupled plasma optical emission spectroscopy; Perkin-Elmer, Optima, 3000 DV). The analyses of As (75), B (10), Ba (137), Cd (111), Co (59), Cr (52), Hg (202), Mo (98), Ni (58), P (31), Pb (208), Se (82), Si (28), Sr (88), Ti (48) and V (51), which were down to the ng/L range, were made by ICP-MS (inductively coupled plasma mass-spectrometry; Perkin Elmer, ELAN-6000). Atomic spectroscopy standards from Perkin-Elmer, Spex, AccuStandard and Merck were used. The analyses give total concentration of the elements, as the isotope ratios in the standards should correspond closely to the normal ratios in earth. Three replicate analyses were performed. Internal quality control with retest of standards was undertaken after every $20^{\text {th }}$ analyses. $\mathrm{NH}_{4}-\mathrm{N}$ and $\mathrm{NO}_{3}-\mathrm{N}$ were analysed using colorimetric methods on a FIA-instrument. $\mathrm{Cl}, \mathrm{SO}_{4}-\mathrm{S}$ and $\mathrm{F}$ were analysed using ion chromatography, $\mathrm{HCO}_{3}$ by $\mathrm{HCl}$ titration and TOC on a Shimadzu TOC-500 instrument. All analyses were performed at the Department of Ecology, Lund University, whose laboratory has taken part in the ITM (Institute of Applied Environmental Research testing program). The results have consistently been within $10 \%$ of the average values of the participating laboratories.

\subsection{Hair Analyses}

The hair samples were washed in acetone while kept in a pair of teflon tweezers, and rotated for 15 - 20 seconds. Then the hair was dried at $40^{\circ} \mathrm{C}$ in an oven. $0.2 \mathrm{~g}$ 
of the hair was digested in ultra clean nitric acid $\left(\mathrm{HNO}_{3}\right)$ in a microwave oven with multi wave function, and transferred to a $50 \mathrm{ml}$ flask. Hair samples were analysed on similar elements as in water samples on ICP-OES and ICP-MS. All analyses were performed at the Department of Ecology, Lund University

\subsection{Vegetable and Soil Analyses}

At the Department of Ecology, Lund University, Sweden, the vegetables were dried at $40^{\circ} \mathrm{C}$ in an oven. $0.2 \mathrm{~g}$ of respective vegetables were digested in ultra clean nitric acid $\left(\mathrm{HNO}_{3}\right)$ in a microwave oven with multi wave function, and transferred to a $50 \mathrm{ml}$ flask. The concentrations of about 35 elements and ions were determined by ICP OES and ICP-MS. Exchangeable amounts of some dominant minerals (especially $\mathrm{Na}, \mathrm{K}, \mathrm{Ca}, \mathrm{Mg}, \mathrm{Al}, \mathrm{Fe}, \mathrm{Mn}$ ) in soil were analysed in extracts of $\mathrm{BaCl}_{2}$.

\subsection{Statistics}

Parametric statistics (Students t-test) were used for elements that showed a normal distribution (checked by Normal Probability Plots, Levene's test). For elements with a skewed distribution, nonparametric statistical processing was applied (Mann-Whitney's U-test). Possible associations between the concentrations of elements were investigated by calculating correlation coefficients (Spearman's rho). P-values $<0.05$ were accepted as statistically significant (two- tailed tests). Simple linear regression analyses were undertaken to elucidate the impact of different predictors on the variation in element and ion concentrations in water. Model fits were checked by means of residual analyses [9]. Calculations were performed using the Statistical Package for the Social Sciences (SPSS version 10.0).

\section{Results}

Results of water and hair are presented from the sampling in 1997, since no significant differences were detected from the second sampling period. Ions are presented without charges.

\subsection{Water Quality}

The highest $\mathrm{Cu}$ concentrations in well waters were found around $\mathrm{pH}$. The highest conductivity and concentrations of $\mathrm{Ca}, \mathrm{Mg}, \mathrm{Na}, \mathrm{Sr}, \mathrm{Ti}, \mathrm{HCO}_{3}$ and $\mathrm{SO}_{4}$ appeared in the range $\mathrm{pH} 7.0$ - 8.0, see Figure 3 for conductivity.

Figure 3 clearly shows the lack of mineral elements, as represented by conductivity, in the acid well waters, $\mathrm{pH}<6.5$. Actually, the $\mathrm{pH}$ of these well waters were all below 6 , but through storage in a freezer, the levels raised approximately $0.5 \mathrm{pH}$ units. It can be noticed that alkaline well waters had maximum conductivity and highest concentrations of a number of elements in the $\mathrm{pH}$ range $6-7$, as mirrored by conductivity.

Median concentrations and ranges of acid and alkaline well waters are presented in Table 1. 




Figure 3. Conductivity vs $\mathrm{pH}$ in the whole material in the study of acid and alkaline well waters, indicating a positive trend in acid water, and a negative trend in alkaline well waters. One spot represents one specific well water.

Conductivity and the concentrations of $\mathrm{NH}_{4}-\mathrm{N}, \mathrm{As}, \mathrm{HCO}_{3}, \mathrm{SO}_{4}-\mathrm{S}, \mathrm{Ca}, \mathrm{Cr}, \mathrm{Mo}$, Se and Sr were all significantly higher $(\mathrm{p}<0.001)$ in well water from the alkaline area as compared with well water from the acid area. The result was similar for $\mathrm{V}, \mathrm{Ni}$ and $\mathrm{K}$ (p-values < 0.04). On the other hand $\mathrm{Ba}, \mathrm{Cd}, \mathrm{Cu}, \mathrm{F}, \mathrm{Pb}$ and $\mathrm{P}(\mathrm{p}<$ $0.001)$ and $\mathrm{NO}_{3}-\mathrm{N}(\mathrm{p}=0.044)$ levels were all significantly higher in the acid waters.

Figure 4 clearly shows the big difference between Ca levels in acid and alkaline well waters, median 6 times higher in alkaline. However, $\mathrm{Mg}$ concentrations are almost the same, since limestone and soils on the Kristianstad flatland is poor in $\mathrm{Mg}$. The elevated $\mathrm{Cu}$ in acid well waters, see Figure 5 above, is due to dissolution from pipes. However, the highest concentration was at $\mathrm{pH} 6$, which can be explained by the high $\mathrm{HCO}_{3}$ levels at $\mathrm{pH} 6$.

The median molar ratio $(\mathrm{Ca}+\mathrm{Mg}+\mathrm{K}) / \mathrm{Al})$ was 239 in acid, and 1412 in alkaline well water $(\mathrm{p}<0.001)$, indicating protection from $\mathrm{Al}$ by the essential elements $\mathrm{Ca}, \mathrm{Mg}$ and $\mathrm{K}$ in well waters from the alkaline area. In addition, the median molar ratio between some micro-nutrients and some toxic elements ( $\mathrm{Se}+$ $\mathrm{Cr}) /(\mathrm{Cd}+\mathrm{Hg}+\mathrm{Pb})$ was 1 in acid, and 172 in alkaline well waters $(\mathrm{p}<0.001)$.

The contribution to the daily intake of mineral elements from well waters is presented in Table 2.

The largest contribution to the daily intake of the essential minerals $\mathrm{Ca}, \mathrm{Mg}$, $\mathrm{Fe}, \mathrm{Na}, \mathrm{K}, \mathrm{Cr}$, Se, Mo and $\mathrm{Zn}$ were from alkaline well waters, while acid well waters provided more of $\mathrm{Cu}$ and $\mathrm{Mn}$ than alkaline. Among alkaline well waters 
Table 1. Median concentrations and ranges of acid and alkaline well waters [10].

\begin{tabular}{|c|c|c|c|c|c|}
\hline & Median acid & Range acid & Median alkaline & Range alkaline & Unit \\
\hline $\mathrm{pH}$ & 6.0 & $4.45-6.45$ & 7.6 & $7.1-8.9$ & \\
\hline Conductivity & 10.8 & $4.9-24.1$ & 29.7 & $5.3-89$ & $\mathrm{mS} / \mathrm{m}$ \\
\hline $\mathrm{NH}_{4}-\mathrm{N}$ & 0.00 & $0.00-0.027$ & 0.044 & $0.02-1.5$ & $\mathrm{mg} / \mathrm{L}$ \\
\hline $\mathrm{Ca}$ & 9.8 & $1.6-25.2$ & 61 & $26-131$ & $\mathrm{mg} / \mathrm{L}$ \\
\hline $\mathrm{Mg}$ & 1.7 & $0.5-5.7$ & 2.1 & $0.5-6.6$ & $\mathrm{mg} / \mathrm{L}$ \\
\hline $\mathrm{K}$ & 2.5 & $0.2-30$ & 3.6 & $0.0-45$ & $\mathrm{mg} / \mathrm{L}$ \\
\hline $\mathrm{Na}$ & 6.2 & $1.9-21$ & 6.4 & $2.6-101$ & $\mathrm{mg} / \mathrm{L}$ \\
\hline $\mathrm{HCO}_{3}$ & 11.4 & $0-51$ & 141 & $68-300$ & $\mathrm{mg} / \mathrm{L}$ \\
\hline $\mathrm{Cl}$ & 11.9 & $3.9-68.4$ & 18.1 & $4.5-180$ & $\mathrm{mg} / \mathrm{L}$ \\
\hline $\mathrm{NO}_{3}-\mathrm{N}$ & 1.8 & $0-16$ & 0.4 & $0.0-30$ & $\mathrm{mg} / \mathrm{L}$ \\
\hline $\mathrm{SO}_{4}-\mathrm{S}$ & 3.6 & $1.7-9.1$ & 8.7 & $0.9-60$ & $\mathrm{mg} / \mathrm{L}$ \\
\hline $\mathrm{Si}$ & 1.2 & $0.3-8.1$ & 1.4 & $0.01-7.8$ & $\mathrm{mg} / \mathrm{L}$ \\
\hline TOC & 0 & 0 & 0.0 & $0.0-0.0$ & $\mathrm{mg} / \mathrm{L}$ \\
\hline $\mathrm{Al}$ & 40 & $4-1080$ & 36 & $22-47$ & $\mu \mathrm{g} / \mathrm{L}$ \\
\hline As & 0.16 & $0.07-0.68$ & 0.5 & $0.08-11.7$ & $\mu \mathrm{g} / \mathrm{L}$ \\
\hline $\mathrm{Ba}$ & 52 & $10-123$ & 7.1 & $1.5-81.7$ & $\mu \mathrm{g} / \mathrm{L}$ \\
\hline B & 10.6 & $3.5-34.7$ & 9.3 & $0.7-106$ & $\mu \mathrm{g} / \mathrm{L}$ \\
\hline $\mathrm{Cd}$ & 0.047 & $0.01-0.40$ & 0.01 & $0.0-0.25$ & $\mu \mathrm{g} / \mathrm{L}$ \\
\hline $\mathrm{Cr}$ & 0.03 & $0.03-0.6$ & 1.8 & $0.1-8.2$ & $\mu \mathrm{g} / \mathrm{L}$ \\
\hline Co & 0.14 & $0-14.2$ & 0.2 & $0.05-1.5$ & $\mu \mathrm{g} / \mathrm{L}$ \\
\hline $\mathrm{Cu}$ & 117 & $6-3200$ & 14 & $0.0-430$ & $\mu \mathrm{g} / \mathrm{L}$ \\
\hline $\mathrm{F}$ & 408 & $0-870$ & 0.0 & $0.0-230$ & $\mu \mathrm{g} / \mathrm{L}$ \\
\hline $\mathrm{Fe}$ & 17 & $3-630$ & 10 & $0.0-2900$ & $\mu \mathrm{g} / \mathrm{L}$ \\
\hline $\mathrm{Pb}$ & 0.50 & $0.04-3.7$ & 0.02 & $0.0-1.4$ & $\mu \mathrm{g} / \mathrm{L}$ \\
\hline $\mathrm{Mn}$ & 18 & $1-325$ & 20 & $2.0-130$ & $\mu \mathrm{g} / \mathrm{L}$ \\
\hline $\mathrm{Hg}$ & 0.02 & $0-0.03$ & 0.02 & $0.0-0.06$ & $\mu \mathrm{g} / \mathrm{L}$ \\
\hline Mo & 0.01 & $0-0.37$ & 2.1 & $0.3-14.8$ & $\mu \mathrm{g} / \mathrm{L}$ \\
\hline $\mathrm{Ni}$ & 0.32 & $0.01-19$ & 0.9 & $0.01-19$ & $\mu \mathrm{g} / \mathrm{L}$ \\
\hline $\mathbf{P}$ & 11.1 & $0.5-34$ & 2.5 & $0.0-73$ & $\mu \mathrm{g} / \mathrm{L}$ \\
\hline $\mathrm{Se}$ & 0.28 & $0.12-0.94$ & 0.5 & $0.12-12$ & $\mu \mathrm{g} / \mathrm{L}$ \\
\hline $\mathrm{Sr}$ & 42.3 & $10.8-168$ & 194 & $59-350$ & $\mu \mathrm{g} / \mathrm{L}$ \\
\hline $\mathrm{Ti}$ & 8.0 & $1.6-36$ & 0.7 & $0.0-210$ & $\mu \mathrm{g} / \mathrm{L}$ \\
\hline $\mathrm{V}$ & 0.17 & $0.05-1.36$ & 0.3 & $0.03-2.1$ & $\mu \mathrm{g} / \mathrm{L}$ \\
\hline $\mathrm{Zn}$ & 58 & $7.0-1100$ & 43 & $1.0-1300$ & $\mu \mathrm{g} / \mathrm{L}$ \\
\hline
\end{tabular}






Figure 4. Median $\mathrm{Ca}, \mathrm{Mg}$ and $\mathrm{HCO}_{3}$ concentrations in acid and alkaline well waters in this study.



Figure 5. Median $\mathrm{Cu}$ and $\mathrm{Ba}$ in this study of acid and alkaline well waters.

Table 2. Mineral elements from well waters in this study and their contribution to the daily intake, recommended or average intake [11] [12] based on a daily consumption of 2 litres of water.

\begin{tabular}{cccc}
\hline $\begin{array}{c}\text { Mineral } \\
\text { element }\end{array}$ & $\begin{array}{c}\text { Recommended or } \\
\text { Common daily intake }\end{array}$ & $\begin{array}{c}\text { Mean contribution to recommended or average } \\
\text { daily in\% (2 Liters consumption), acid area }\end{array}$ & $\begin{array}{c}\text { Mean contribution to recommended or average daily } \\
\text { intake in\% (2 Liters consumption), alkaline area }\end{array}$ \\
\hline $\mathrm{Ca}$ & $800 \mathrm{mg}$ & 2.7 & 14 \\
$\mathrm{Mg}$ & $280 \mathrm{mg}$ & $<1$ & 5 \\
$\mathrm{Na}$ & $<1000 \mathrm{mg}$ & 1,5 & 0.5 \\
$\mathrm{~K}$ & $2000 \mathrm{mg}$ & 0.4 & 6.6 \\
$\mathrm{Cl}$ & $800 \mathrm{mg}$ & 4.3 & 2.5 \\
$\mathrm{Fe}$ & $14 \mathrm{mg}$ & 0.6 & 3 \\
$\mathrm{Zn}$ & $10 \mathrm{mg}$ & 2.4 & 2.4 \\
$\mathrm{Mn}$ & $2 \mathrm{mg}$ & 4.1 & 17 \\
$\mathrm{Cu}$ & $1 \mathrm{mg}$ & 70 & 18 \\
$\mathrm{Cr}$ & $40 \mathrm{micg}$ & 1 & 4 \\
$\mathrm{Se}$ & $50 \mathrm{micg}$ & 1.2 & 14 \\
$\mathrm{Mo}$ & $50 \mathrm{micg}$ & 0.4 & 2 \\
\hline
\end{tabular}


there were waters that provided $33 \%$ to the daily intake of $\mathrm{Ca}$, and $46 \%$ of $\mathrm{Fe}$, while among acid well waters one provided $256 \%$ to the daily $\mathrm{Cu}$ intake, and one $62 \%$ to $\mathrm{F}$ intake, indicating that the assumed $10 \%$ contribution from drinking water can be exceeded for consumers of especially private well waters, while especially acid well waters may give no contribution at all.

\subsection{Soil/Vegetable Quality}

Only Mo $(\mathrm{p}<0.001)$ concentrations were significantly higher in all the different vegetables from the alkaline district compared to vegetables from the acid areas. On the other hand $\mathrm{Ba}, \mathrm{Br}, \mathrm{Mn}, \mathrm{Rb}$ and $\mathrm{Zn}$ were significantly higher $(\mathrm{p}<0.001$ 0.008 ) in vegetables from the acid area. Only Ca concentrations in soil from the alkaline area were significantly higher $(\mathrm{p}=0.01)$ than in soil from the acid area. $\mathrm{Fe}, \mathrm{Mn}$ and $\mathrm{Na}$ were higher $(\mathrm{p}<0.001)$ in soil samples from the acid area [13].

\subsection{Water Consumption}

Median number of litres of well water consumed including soup, coffee etc. was $1.4 \mathrm{~L}$ among women with acid well waters, and $1.5 \mathrm{~L}$ for women drinking alkaline well waters.

\subsection{Hair Analysis}

Median element concentrations in hair of women drinking acid and alkaline well waters, respectively, are presented in Table 3.

$\mathrm{B}, \mathrm{Ba}$ and $\mathrm{Cu}$ concentrations were significantly higher in "acid hair" ( $\mathrm{p}<$ 0.002), while $\mathrm{Ca}, \mathrm{Mo}, \mathrm{Fe}, \mathrm{Se}$ and Sr levels were significantly higher in "alkaline hair" ( $p<0.001)$. Se concentrations in hair samples from the acid area were below the detection limit $(5 \mathrm{ng} / \mathrm{g}$ ) in 39 out of 47 samples. Strong positive correlations were observed between element concentrations in hair and water for $\mathrm{Ca}\left(\mathrm{r}_{\mathrm{s}}\right.$ $=0.57 ; \mathrm{p}<0.001), \mathrm{Sr}\left(\mathrm{r}_{\mathrm{s}}=0.46 ; \mathrm{p}<0.001\right), \mathrm{Mo}\left(\mathrm{r}_{\mathrm{s}}=0.52 ; \mathrm{p}<0.001\right)$ and $\mathrm{Pb}\left(\mathrm{r}_{\mathrm{s}}=\right.$ $0.34 ; \mathrm{p}=0.001)$, indicating that water minerals are mirrored in hair and important for body mineral content.

Median Ca levels in alkaline well waters were 6 times higher than acid. The same pattern was found in women's hair, see Figure 6.

Significantly different ratios in hair were $(\mathrm{Ca}+\mathrm{Mg}+\mathrm{K}) / \mathrm{Al}) ; 177$ in acid and 804 in alkaline; $(\mathrm{Se}+\mathrm{Cr}) /(\mathrm{Cd}+\mathrm{Hg}+\mathrm{Pb}) 0.2$ in acid and 0.5 in alkaline, respectively, which indicates protection from toxic elements by essential ones in "alkaline" hair.

\subsection{Health Effects/Outcomes}

Number of reported health changes occurring during the time women had been drinking their specific well water are presented in Figure 7 [15].

Figure 7 clearly shows the difference in health status between the two groups. There was no difference in food habits, indicating the importance of drinking water quality. 
Table 3. Median concentrations and ranges of elements in hair of women drinking acid well water, "acid hair", and women drinking alkaline well water, "alkaline hair" [14].

\begin{tabular}{|c|c|c|c|c|c|}
\hline & Median "acid hair" & Range "acid hair" & Median "alkaline hair" & Range "alkaline hair" & Unit \\
\hline $\mathrm{Ca}$ & 283 & $50-2830$ & 1290 & $231-5630$ & $\mu \mathrm{g} / \mathrm{g}$ \\
\hline $\mathrm{Mg}$ & 26.4 & $9.5-424$ & 32.2 & $7.2-299$ & $\mu \mathrm{g} / \mathrm{g}$ \\
\hline $\mathrm{K}$ & 41.1 & $1.25-3370$ & 54.6 & $3.5-1780$ & $\mu \mathrm{g} / \mathrm{g}$ \\
\hline $\mathrm{Na}$ & 74.1 & $19.7-5600$ & 123 & $22-2850$ & $\mu \mathrm{g} / \mathrm{g}$ \\
\hline $\mathrm{Al}$ & 5.2 & $1.4-21.4$ & 3.4 & $0.2-21.4$ & $\mu \mathrm{g} / \mathrm{g}$ \\
\hline $\mathrm{Cu}$ & 47.4 & $6.1-716$ & 19.8 & $8.3-179$ & $\mu g / g$ \\
\hline $\mathrm{Fe}$ & 9.53 & $0.25-29.3$ & 18.4 & $6.12-195$ & $\mu \mathrm{g} / \mathrm{g}$ \\
\hline $\mathrm{Mn}$ & 0.355 & $0.050-8.554$ & 0.503 & $0.071-25.2$ & $\mu \mathrm{g} / \mathrm{g}$ \\
\hline $\mathrm{Hg}$ & 0.376 & $0.012-3.503$ & 0.327 & $0.086-0.960$ & $\mu \mathrm{g} / \mathrm{g}$ \\
\hline $\mathrm{Ni}$ & 0.354 & $0.055-2.15$ & 0.248 & $0.006-4.64$ & $\mu \mathrm{g} / \mathrm{g}$ \\
\hline $\mathrm{Rb}$ & 0.054 & $0.0025-6.68$ & 0.064 & $0.007-2.054$ & $\mu \mathrm{g} / \mathrm{g}$ \\
\hline $\mathrm{Sr}$ & 0.627 & $0.021-8.61$ & 2.64 & $0.312-13.2$ & $\mu \mathrm{g} / \mathrm{g}$ \\
\hline $\mathrm{Ti}$ & 0.958 & $0.128-13.86$ & 1.2 & $0.54-4.30$ & $\mu \mathrm{g} / \mathrm{g}$ \\
\hline $\mathrm{Zn}$ & 163 & $84-278$ & 174 & $73-240$ & $\mu \mathrm{g} / \mathrm{g}$ \\
\hline $\mathrm{P}$ & 130 & $81-340$ & 119 & $26-192$ & $\mu \mathrm{g} / \mathrm{g}$ \\
\hline S & 42,500 & $30,200-50,200$ & 43,800 & $41,500-51,700$ & $\mu \mathrm{g} / \mathrm{g}$ \\
\hline As & 17 & $3.9-64$ & 22 & $7.4-99$ & $\mathrm{ng} / \mathrm{g}$ \\
\hline $\mathrm{Ba}$ & 1057 & $10-7150$ & 324 & $10-2130$ & $\mathrm{ng} / \mathrm{g}$ \\
\hline B & 281 & $0.5-7070$ & 0.5 & $0.5-18,400$ & $\mathrm{ng} / \mathrm{g}$ \\
\hline $\mathrm{Cd}$ & 16 & $2.5-227$ & 30 & $2.5-253$ & $\mathrm{ng} / \mathrm{g}$ \\
\hline $\mathrm{Cr}$ & 167 & $20-659$ & 207 & $77-3690$ & $\mathrm{ng} / \mathrm{g}$ \\
\hline Co & 8.4 & $2.5-702$ & 16 & $2.5-267$ & $\mathrm{ng} / \mathrm{g}$ \\
\hline $\mathrm{Pb}$ & 755 & $7.5-9480$ & 612 & $109-2180$ & $\mathrm{ng} / \mathrm{g}$ \\
\hline Mo & 12.8 & $0.5-190$ & 29 & $7.5-311$ & $\mathrm{ng} / \mathrm{g}$ \\
\hline Se & $<5$ & $1.8-119$ & 127 & $2.5-335$ & $\mathrm{ng} / \mathrm{g}$ \\
\hline $\mathrm{V}$ & 10 & $1.0-98$ & 24 & $9.4-58$ & $\mathrm{ng} / \mathrm{g}$ \\
\hline
\end{tabular}

\section{Discussion}

The results indicate that most essential minerals and ions in dug well water in studied areas appear at highest concentrations in the pH-range 7 - 8. Especially Ca precipitates as $\mathrm{CaSO}_{4}$ and $\mathrm{CaCO}_{3}$ at elevated $\mathrm{pH}$ levels, and at lower $\mathrm{pH}$ many minerals are washed out of soils.

The importance of mineral-rich drinking water for the human health has been clearly stated by e.g. Schroeder (1966) [16], Rubenowitz et al. $(1996,2000)$ [17] [18], Rylander (1991) [19], Costi et al. (1999) [20], and Yang et al. (1999, 2002) [21] [22] who had focus on $\mathrm{Ca}, \mathrm{Mg}$, while Rylander (2008) [23] also included 




Figure 6. Median hair concentration of $\mathrm{Ca}$ of women drinking acid well water vs. alkaline.

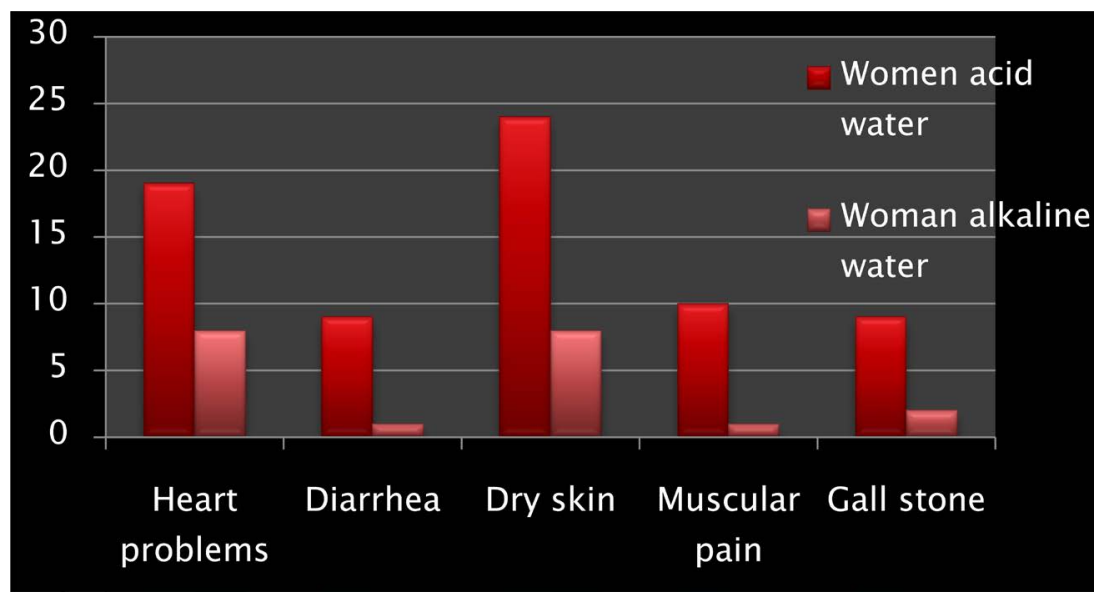

Figure 7. Reported negative health changes during the time women had been drinking their specific well water [15].

$\mathrm{HCO}_{3}$. Ca is needed especially for proper teeth and bones, but also proper muscle function, including heart function, and $\mathrm{Mg}$ acts as a cofactor for nearly 300 enzymes important for energy production and storage, the carbohydrate metabolism, heart, muscles, bones and nerve impulses [12]. $\mathrm{HCO}_{3}$ is the major buffering agent in the body. Elevated $\mathrm{HCO}_{3}$ concentration in drinking water helps in minimizing urinary loss of $\mathrm{Ca}$ and $\mathrm{Mg}$ [24] [25]. Such losses are a consequence of acidification of the body, which in turn can be a consequence of drinking low mineral water [23] [26], as e.g. acid well water.

In USA a panel of experts found that areas of the US with the highest longevity of humans had on average $20 \mathrm{mg} / \mathrm{L} \mathrm{Mg}$ and $245 \mathrm{mg} / \mathrm{L} \mathrm{HCO}_{3}$ [27]. These concentrations are very high compared to the values in acid areas in this study, median $\mathrm{Mg} 1.7 \mathrm{mg} / \mathrm{L}$ and $\mathrm{HCO}_{3} 11.4 \mathrm{mg}$. However, alkaline area dug wells were also low in $\mathrm{Mg}$, median $2.1 \mathrm{mg} / \mathrm{L}$. Thus, the low concentrations of especially Ca 
and $\mathrm{HCO}_{3}$ in acid well waters more likely explain the higher frequency of reported negative health changes of women living in the acid region. Hair of women in the acid area was also low in Ca compared to women from the alkaline district, 6 times lower, mirroring the mineral levels in water.

Magnesium from drinking water is more scientifically recognized as important for the human health than calcium. In a study, Leurs et al. (2010) [28] found that for men with a low dietary magnesium intake, a significant inverse association was found between tap water magnesium level and stroke mortality. The current position in health authorities, led by WHO, was stated in WHO (2011a) [29]; "although, there is some evidence for a protective effect of magnesium or hardness on cardiovascular mortality, the evidence is being debated and does not prove causality". However, it is stated that drinking-water may be an important source of calcium and magnesium for those who are marginal for calcium and magnesium intake. WHO considers current data as insufficient for suggesting either minimum or maximum concentrations of minerals, but does not specify what kind of studies would provide convincing data. However, Rosborg et al. (2014) [30] suggest ranges for a number of nutrient minerals; Ca $20-80 \mathrm{mg} / \mathrm{L}$, $\mathrm{Mg} 10-50 \mathrm{mg} / \mathrm{L}, \mathrm{HCO}_{3} 100-300 \mathrm{mg} / \mathrm{L}$, and $\mathrm{SO}_{4} 50-250 \mathrm{mg} / \mathrm{L}$, as a starting point for future regulations, where the lower limit should be regarded as an absolute minimum.

The low Mo, Fe and Se levels in hair of women drinking acid well water, with most Se concentrations below the detection limit, may also contribute to the increased number of reported negative health changes. Se is a powerful antioxidant; $\mathrm{Fe}$ is needed especially for the oxygen transport and storage, while Mo is crucial for proper liver function [12]. In addition, the higher $(\mathrm{Ca}+\mathrm{Mg}+\mathrm{K}) / \mathrm{Al})$, and $(\mathrm{Se}+\mathrm{Cr}) /(\mathrm{Cd}+\mathrm{Hg}+\mathrm{Pb})$ ratios in alkaline well water compared to acid, indicate protection against acidification of the body and toxic elements for women drinking alkaline well water. However, elevated Fe concentrations, $>1 \mathrm{mg} / \mathrm{L}$, may cause especially diarrhoea in sensitive persons [31]. Three alkaline well waters had $\mathrm{Fe}$ concentration $>1 \mathrm{mg} / \mathrm{L}$. None of these women reported diarrhoea or other intestinal disturbances. However, men are generally more affected, since women loose Fe through menstruation, during their period before about 50 years of age.

$\mathrm{Cu}$ is an essential element, part of many enzymes and needed for proper $\mathrm{Fe}$ utilization. However, excess $\mathrm{Cu}$ may lead to especially diarrhoea and Wilson's disease, where $\mathrm{Cu}$ accumulates in the liver, brain and eyes, and ends in hepatic cirrhosis, and neurological degeneration [32]. The $\mathrm{Cu}$ maximum at $\mathrm{pH} 6$ deviates from earlier findings, as a $\mathrm{Cu}$ peak generally is found in alkaline waters containing organic matter [33] [34], or elevated $\mathrm{HCO}_{3}$ [35]. In this stud, $\mathrm{HCO}_{3}$ concentrations peaked at $\mathrm{pH}$, which did also copper. The alkaline waters in this study all had TOC (Total Organic Matter) below the detection limit, contributing to the low $\mathrm{Cu}$ concentrations in alkaline well waters. Even though water samples were taken after $1 / 2$ minute of flushing, some samples from the acid 
area were very high in $\mathrm{Cu}$ concentration. From one sample, $3.2 \mathrm{mg} / \mathrm{L}$, and well above the WHO guideline value (2011b) [36] of $2 \mathrm{mg} / \mathrm{L}$, the contribution to the daily intake for an infant drinking $0.8 \mathrm{~L}$ per day, would be $2.56 \mathrm{mg}$, which is 128 times the recommended value of $0.01 \mathrm{mg}$ [37], if 50\% absorption is assumed. High $\mathrm{Cu}$ levels may cause intestinal problems, e.g. diarrhoea, especially on infants fed infant formula prepared on such water [38] [39], which may be due to a direct toxic effect, but also in the long run an anti-microbial effect in the intestines, causing additional problems [40].

The contribution to the daily intake of the essential minerals $\mathrm{Ca}, \mathrm{Mg}, \mathrm{Fe}, \mathrm{Na}$, $\mathrm{K}, \mathrm{Cr}$, Se, Mo and $\mathrm{Zn}$ were in many cases $0 \%$ from acid well waters, while those well waters provided too much of especially $\mathrm{Cu}, \mathrm{F}$ and $\mathrm{Mn}$, causing an imbalance between some essential elements and potentially toxic concentrations of others. There were alkaline well waters in this study that provided $33 \%$ to the daily intake of $\mathrm{Ca}$, and $46 \%$ of $\mathrm{Fe}$, while in many cases the contribution was $0 \%$ from acid well waters, clearly showing that the expected 10\% from drinking water [29] may be exceeded especially for people consuming private well waters, while especially acid well waters may give no contribution at all. Specific acid waters provided as much as $256 \%$ of the daily $\mathrm{Cu}$ intake, and $62 \%$ of $\mathrm{F}$, possibly causing toxic effects in consumers. The health based guideline value for $\mathrm{F}$ is $1.5 \mathrm{mg} / \mathrm{L}$, where levels above may cause stains on teeth [36].

No other element than Mo $(\mathrm{p}<0.001)$ was significantly higher in vegetables from the alkaline area than in those from the acid district, while a number of essential elements, $\mathrm{HCO}_{3}, \mathrm{SO}_{4}-\mathrm{S}, \mathrm{Ca}, \mathrm{Cr}, \mathrm{Mo}$ and $\mathrm{Se}$, were higher in alkaline well waters than in acid, indicating that the influence on hair mineral elements from vegetables is negligible, but important from drinking water.

The differences in mineral levels of both soils and vegetables in the two areas were very small. This finding indicates that the soils, where vegetables were cultivated, probably have been drained of minerals, but also fertilized up to similar levels. The contribution of mineral elements to the daily intake was minor from the analysed vegetables, except for some samples of lettuce from the alkaline area, in contrast to the well water situation. Thus, the contribution to the daily recommended, presumed consumption of lettuce $19 \mathrm{~g} /$ day, intake was $15 \%$ in one sample of lettuce, $68 \%$ of Mo in another, $9 \%$ of Fe in a third one, while two samples from the acid area provided $42 \%$ of $\mathrm{Mn}$ and $16 \%$ of $\mathrm{Zn}$, respectively. All other contributed less than $3 \%$ to the daily intake [13].

This minor study was presented on the $9^{\text {th }}$ Conference on Acid Deposition, Acid Rain, Rochester, USA, 19-23 October, 2015, as the only study, ever, on the impact of Acid Rain on human health. Thus, there is need for studies of the influence of acid well water on human and animal health in areas where acidification is currently in an acute stage.

\section{Conclusions}

- The concentrations of a large number of nutrient minerals were significantly 
higher in tap water and women's hair from the alkaline area as compared with well water and hair from the acid area.

- The element ratios $(\mathrm{Ca}+\mathrm{Mg}+\mathrm{K}) / \mathrm{Al})$ and $(\mathrm{Se}+\mathrm{Cr}+\mathrm{As}) /(\mathrm{Cd}+\mathrm{Hg}+\mathrm{Pb})$ were significantly higher in alkaline well waters than in acid, indicating protection from the toxic metals in alkaline waters.

- $\mathrm{Cu}$ concentration in drinking water was extreme in some acid well waters, which can be a cause of especially diarrhea, but also nausea (not described by women in this study).

- Drinking water minerals were mirrored in hair composition, and support the theory that hair mineral content is an important indicator of mineral intake.

- Women drinking acid well waters reported a lot more negative health changes during the time they had been drinking their specific well water (at least 5 years).

- Among alkaline well waters there were waters that provided much more than predicted $10 \%$ to the daily intake of especially $\mathrm{Ca}$ and $\mathrm{Fe}$, while often close to $0 \%$ from acid waters.

- The contributions of $\mathrm{Cu}, \mathrm{F}$ and $\mathrm{Mn}$ were high from acid waters.

- Vegetable minerals (vegetables cultivated in the kitchen garden of participating women) were not mirrored in the hair mineral composition, indicating the greater importance of minerals from drinking water.

\section{Acknowledgements}

It's with great gratitude we mention Högskolan Kristianstad, and the municipalities of Hässleholm and Härryda that together made this study possible.

\section{References}

[1] Kalén, C. (1998) Forests, Acidification and the Socioeconomic Costs. Department of Plant Ecology, Institute of Ecology, Lund University, Lund, 1.

[2] SGU (2017). http://www.sgu.se

[3] Nordberg, G.F., Goyer, R.A. and Clarkson, T.W. (1985) Impact of Effects of Acid Precipitation on Toxicity of Metals. Environmental Health Perspectives, 63, 169-180. https://doi.org/10.1289/ehp.8563169

[4] Bertills, U. and Hanneberg, P. (1995) Acidification in Sweden. What Do We Know Today? SEPA, Report 4422, 58-68.

[5] Thuvander, A. and Oskarsson, A. (1997) Adverse Health Effects Due to Soil and Water Acidification. Swedish Environment Protection Agency, SEPA Report 4881, 32-33

[6] Skolvision (2016). http://www.skolvision.se/DelLimnologi/Acid/pHlake400.jpg

[7] Thuvander, A. and Oskarsson, A. (1997) Adverse Health Effects Due to Soil and Water Acidification. SEPA Report 4881, Swedish Environment Protection Agency, 32-33.

[8] Aastrup, M., Thunholm, B., Johnson, J., Bertills, U. and Berntell, A. (1995) The Chemistry of Ground Water. The Swedish Bed-Rock, SEPA Report 4415.

[9] Altman, D.G. (1991) Practical Statistics for Medical Research. Chapman \& Hall, 
London.

[10] Rosborg, I., Gerhardsson, L. and Nihlgård, B. (2002) Inorganic Constituents of Well Water in One Acid and One Alkaline Area of South Sweden. Water, Air, \& Soil Pollution, 142, 261-277. https://doi.org/10.1023/A:1022078925064

[11] NFAS (National Food Agency, Sweden) (2018). https://www.livsmedelsverket.se/livsmedel-och-innehall/text-pa-forpackning-mark ning/naringsvarde

[12] Bowman, B.A. and Russell, R.M. (2006) Nutrition. 9th Edition, ILSI, Washington DC, $526 \mathrm{p}$.

[13] Rosborg, I., Nihlgård, B. and Gerhardsson, L. (2009) Mineral Element Concentrations in Vegetables Cultivated in Acid Compared to Alkaline Areas of South Sweden. Air Soil and Water Research, 2, 15-29. https://doi.org/10.4137/ASWR.S1004

[14] Rosborg, I., Nihlgård, B. and Gerhardsson, L. (2003) Hair Element Concentrations in Females in One Acid and One Alkaline Area in South Sweden. Ambio, 32, 440. https://doi.org/10.1579/0044-7447-32.7.440

[15] Rosborg, I. (2005) Mineral Element Contents in Drinking Water-Aspects on Quality and Potential Links to Human Health. Doctoral Thesis, Lund University, Lund.

[16] Fenniae, A.P. (1965) Annales de Pediatrie, Paris. JAMA, 195, 181.

[17] Rubenowitz, E., Axelsson, G. and Rylander, R. (1996) Magnesium in Drinking Water and Death from Acute Myocardial Infarction. American Journal of Epidemiology, 143, 456-462. https://doi.org/10.1093/oxfordjournals.aje.a008765

[18] Rubenowitz, E., Molin, I., Axelsson, G. and Rylander, R. (2000) Magnesium in Drinking Water in Relation to Morbidity and Mortality from Acute Myocardial Infarction. Epidemiology, 11, 416-421. https://doi.org/10.1097/00001648-200007000-00009

[19] Rylander, R., Bonevik, H. and Rubenowitz, E. (1991) Mg and Ca in Drinking Water and Cardiovascular Mortality. Scandinavian Journal of Work, Environment \& Health, 17, 91-94. https://doi.org/10.5271/sjweh.1722

[20] Costi, D., Calcaterra, P.G., Iori, N., Vourna, S., Nappi, G. and Passeri, M. (1999) Importance of Bioavailable Calcium in Drinking Water for the Maintenance of Bone Mass in Post-Menopausal Women. Journal of Endocrinological Investigation, 22, 852-856. https://doi.org/10.1007/BF03343658

[21] Yang, C.-Y., Chiu, H.-F., Cheng, M.-F., Tsai, S.-S., Hung, C.-F. and Lin, M.-C. (1999) Esophageal Cancer Mortality and Total Hardness Levels in Taiwan's Drinking Water. Environmental Research, 81, 302-308. https://doi.org/10.1006/enrs.1999.3991

[22] Yang, C.-Y., Chiu, H.-F., Chang, C.-C., Wu, T.-N. and Sung, F.-C. (2002) Association of Low Birth Weight with Calcium Levels in Drinking Water. Environmental Research, 89, 189-194.

[23] Rylander, R. (2008) Drinking Water Constituents and Disease. The Journal of Nutrition, 138, 423s-425s. https://doi.org/10.1093/jn/138.2.423S

[24] Hu, J.F., Zhao, X.H., Parpia, B. and Campbell, T.C. (1993) Dietary Intakes and Urinary Excretion of $\mathrm{Ca}$ and Acids: A Cross-Sectional Study of Women in China. The American Journal of Clinical Nutrition, 58, 398-406. https://doi.org/10.1093/ajcn/58.3.398

[25] Rylander, R., Remer, T., Berkemeyer, S. and Vormann, J. (2006) Acid-Base Status Affects Renal Mg Losses in Healthy, Elderly Persons. The Journal of Nutrition, 136, 
2374-2377.

[26] CDC (1994) Hyponatremic Seizures among Infants Fed with Commercial Bottled Drinking Water-Wisconsin. $M M W R, 43,641-643$.

[27] US NAS (1981) Aging and the Geochemical Environment-A Report of the Panel Appointed by US National Academy of Sciences.

[28] Leurs, L.J., Schouten, L.J., Mons, M.N., Goldbohm, R.A. and van den Brandt, P.A. (2010) Relationship between Tap Water Hardness, Magnesium, and Calcium Concentration and Mortality due to Ischemic Heart Disease or Stroke in the Netherlands. Environmental Health Perspectives, 118, 414-420. https://doi.org/10.1289/ehp.0900782

[29] WHO (2011) Hardness in Drinking Water. Background Document for Development for WHO Guidelines for Drinking Water Quality.

[30] Rosborg, I., Kozisek, F., Brenner, A., Jovanovic, D., Nihlgard, B., Selinus, O., Russell, L., Persson, K.M., Soni, V. and Ferrante, M. (2014) Drinking Water Minerals and Mineral Balance-Importance, Health Significance, Safety Precautions. Springer Verlag, Berlin, 140 p.

[31] Rosborg, I. (2015) Elevated Iron Concentrations in Drinking Water: A Potential Health Risk. International Journal of Environmental Science and Toxicology Research, 3, 66-74.

http://www.internationalinventjournals.org/journals/IJESTR/Archive/2015/May_V ol-3-issue-5/toc.html

[32] WHO (1996) Trace Elements in Human Nutrition and Health. WHO, Geneva.

[33] Korshin, G.V., Perry, S.A.L. and Ferguson, J.F. (1996) Influence of NOM on Copper Corrosion. Journal $A W W A, \mathbf{8 8}, 36-46$.

[34] Holmström, H. and Swedling, E.-O. (1997) Vatten (Water). Föreningen Vatten, 53, 191-196.

[35] Edwards, M., Chock, M.R. and Travis, E.M. (1996) Alkalinity, pH and Copper Corrosion By-Product, Release. Journal $A W W A, 88,81-94$.

[36] WHO (2011) Guidelines for Drinking Water Quality. 4th Edition. WHO, Geneva.

[37] NFAS (National Food Agency, Sweden) (2017). http://www.livsmedelsverket.se

[38] Knobeloch, I., Ziarnic, M., Howard, J., Theis, B., Farmer, D., Anderson, H. and Proctor, M. (1994) Gastrointestinal Upsets Associated with Ingestion of Copper-Contaminated Water. Environmental Health Perspectives, 102, 958-961. https://doi.org/10.1289/ehp.94102958

[39] Stenhammar, L. (1999) Diarrhoea Following Contamination of Drinking Water with Copper. European Journal of Medical Research, 28, 217-218.

[40] Grimsdottir, M.R. and Hensten-Pettersen, A. (1993) Cytotoxical and Antibacterial Effects of Orthodentic Appliances. Scandinavian Journal of Dental Research, 101, 229-231. 